\title{
Radicle emergence test as a quick vigour test to predict field emergence performance in rice (Oryza sativa L.) seed lots
}

\author{
Chinnasamy G P* \\ Department of Seed Science and Technology, Tamil Nadu Agricultural University, \\ Coimbatore - 641003 (Tamil Nadu) India \\ Sundareswaran $\mathbf{S}$ \\ Directorate of Seed Centre, Tamil Nadu Agricultural University, Coimbatore - 641003 \\ (Tamil Nadu) India

\section{Renganayaki P R} \\ Department of Seed Science and Technology, Tamil Nadu Agricultural University, \\ Coimbatore - 641003 (Tamil Nadu) India

\section{Vetrivel M} \\ Department of Crop Physiology, Tamil Nadu Agricultural University, Coimbatore - 641003 \\ (Tamil Nadu) India \\ *Corresponding author. Email: chinnasamy1051@gmail.com
}

\section{How to Cite}

Chinnasamy, G. P. et al. (2021). Radicle emergence test as a quick vigour test to predict field emergence performance in rice (Oryza sativa L.) seed lots. Journal of Applied and Natural Science, 13 (SI), 86 - 93. https://doi.org/10.31018/jans.v13iSI.2805

\begin{abstract}
An experiment was made to standardize the radicle emergence test to predict the field emergence performance in ten different seed lots $\left[L_{1}\right.$ to $L_{4}$ : high vigour lots (>90\% germination), $L_{5}$ to $L_{7}$ : medium vigour lots (80-90\% germination) and $L_{8}$ to $L_{10}$ : low vigour lots $(<80 \%$ germination)] of rice cv. CO 51 . The results showed that the significant differences are observed in physiological and biochemical parameters in different seed lots. The seed vigour was classified into three groups viz., high, medium and low vigour based on the relationship between mean germination time and field emergence. When the Mean Germination Time (MGT) was < 34 hours, the field emergence was > 85 per cent, which was considered as high vigour; when the MGT was 34-35 hours, the field emergence was 80-85 per cent, that was considered as medium vigour; when the MGT was > 35 hours, the field emergence was $<80$ per cent, that was considered as low vigour. The radicle emergence test (2mm radicle length) was highly negatively correlated with mean germination time $\left(-0.930^{* *}\right)$ followed by mean just germination time $\left(-0.852^{* \star}\right)$ and electrical conductivity of seed leachate $\left(-0.827^{\star \star}\right)$ and it was positively correlated with field emergence $\left(0.894^{\star \star}\right)$ followed by germination $\left(0.878^{* *}\right)$ and dehydrogenase activity $\left(0.864^{* *}\right)$. The $R^{2}$ values between seed vigour parameters and radicle emergence test were significantly higher in $2 \mathrm{~mm}$ length of radicle emergence when compared with $1 \mathrm{~mm}$ length of radicle emergence. Finally, the study concluded that 36 hour MGT with the attainment of $2 \mathrm{~mm}$ radicle emergence percentage could be used as a quick method to assess rice seed lots' quality by the seed analysts and seed industry.
\end{abstract}

Keywords: Field emergence, Germination, Radicle emergence, Rice, Vigour

\section{INTRODUCTION}

Rice (Oryza sativa L.) is the important staple food of more than $60 \%$ of world's population and it belongs to the family Poaceae. It is a major cereal crop of high agronomic and nutritional importance as global rice production is over 650 million tonnes. In India, rice is grown in an area of 43.2 million hectares with a production of 110.15 million tonnes and productivity of 2.5 tonnes/ha during 2016-17. Tamil Nadu alone contributes an area of 2.04 million hectares with the produc- tion of 7.98 million tonnes and it accounts for the productivity of 3.8 tonnes/ha (Indiastat, 2018-19, https://www.indiastat.com).

Seed is considered as the prime input in agriculture. The quality of the seed is most important to produce vigourous and healthy plants in the field. A key component of crop seeds' performance in field largely depends on the seed vigour (Qun et al., 2007).

International Seed Testing Association defined that 'Seed vigour is the sum of those properties that determine the activity and performance of seed lots of ac- 
ceptable germination in an open array of environments'. Vigour test provides a reproducible result that accurately describes the potential for rapid, uniform emergence under field conditions and describes the ranking of seed lots (International Seed Testing Association, 2014).

Evaluation of seed vigour is important to predict the planting value of seed lot. The use of vigour tests, such as determining their physiological quality by seedproducing industries, has been increasing. However, the vigour tests hope to select the seed lots with good storage capacity. The seed lots with same germination per cent varying vigour in their performance either in storage and field. Hence, the use of good quality seed is obligatory, which necessitates the evaluation of its quality before introducing into market. Seed vigour tests should be inexpensive, rapid, simple, objective, reproducible, and should have high correlation with field performance (International Seed Testing Association, 2016).

The standard germination test is a universal test for seed quality to evaluate the maximum potential of a particular seed lot only under a wide range of climatic conditions. Standard germination test is time consuming and does not always show seed lot potential performance, especially if field conditions are not optimal (Mavi et al., 2016).

Seed lots that do not differ in germination may differ in deterioration level and may differ substantially in-field performance; thereby, a vigour test is considered powerful when it classified the seed lots into more groups or levels (Kolasinska et al., 2000). Radicle emergence test is considered as a quick test to predict varying vigour level and field performance of seed lots than the standard germination test in several crops. Radicle emergence is defined as the appearance of a radicle after breaking through the seed coat. The radicle emergence test has been accepted as a valid seed quality test by the International Seed Testing Association (ISTA) in the Annual Meeting held at Zurich in June 2011 for Zea mays (Matthews and Powell, 2011).

The radicle emergence test provides small laboratories with the opportunity to gain early information to predict the normal seedlings (Mavi et al., 2016). Farmers easily practice for radicle emergence test and do not require sophisticated equipment or highly skilled personnel and it could be used to shorten the decision period in the seed industry management.

The present study was undertaken to standardize the radicle emergence test to predict field emergence performance in rice cv. CO 51 seed lots.

\section{MATERIALS AND METHODS}

The present experiment was conducted to standardize the radicle emergence test to predict field emergence performance in ten different seed lots $\left[L_{1}\right.$ to $L_{4}$ : high vigour lots (> $90 \%$ germination), $L_{5}$ to $L_{7}$ : medium vigour lots ( $80-90 \%$ germination) and $L_{8}$ to $L_{10}$ : low vigour lots $(<80 \%$ germination)] of rice. Genetically pure ten seed lots of rice cv. CO 51 obtained from the Department of Rice, Tamil Nadu Agricultural University, Coimbatore produced the base material for this experimental study. The laboratory and greenhouse studies were carried out in the Department of Seed Science and Technology, Tamil Nadu Agricultural University, Coimbatore, during 2018-2019.

\section{Standard germination test}

The germination test was conducted with 100 seeds in four replications for each lot in the roll towel paper method. The test conditions of $25 \pm 2^{\circ} \mathrm{C}$ temperature and $95 \pm 2 \% \mathrm{RH}$ were maintained in the germination room. At $14^{\text {th }}$ day end of the germination test period, the number of normal seedlings were counted and the mean was expressed as germination percent (International Seed Testing Association, 2016).

The seeds showing plumule emergence in each lot, replication wise were counted daily from the third day after sowing until the germination test. From the number of seeds germinated on each day, the speed of germination was calculated as per the method suggested by Maguire (1962) and the speed of germination results were expressed in number.

At the time of germination count, ten normal seedlings were selected at random from each lot replication wise and the root length was measured from the collar region to the tip of the primary root. The mean values were calculated and expressed in centimetre. The shoot length was measured from the collar region to the tip of the primary leaves and the mean values were expressed in centimetre.

For dry matter production, the seedlings selected for root and shoot length measurements were put inside a paper cover, first shade dried for $24 \mathrm{~h}$ and then dried in a hot air oven maintained at $80 \pm 2^{\circ} \mathrm{C}$ for $24 \mathrm{~h}$. Then the seedlings of dry weight was weighed using an electronic balance and the mean values were expressed in g 10 seedling $^{-1}$.

Vigour index values were computed using the following formula suggested by Abdul-Baki and Anderson (1973). The mean values were expressed as whole numbers. Vigour index $=$ Germination $(\%) x$ seedling length $(\mathrm{cm})$ ........Eq. 1

\section{Radicle emergence (RE) test}

Radicle emergence test was conducted through Top of the paper method. Eight replicates of 25 seeds in each lot were placed on germination paper moistened with distilled water in petri - dish. The petri - dishes were kept in germination room maintained at $25 \pm 2{ }^{\circ} \mathrm{C}$ and relative humidity of $95 \pm 2 \%$. The number of seeds that had produced the radicle of $1 \mathrm{~mm}$ and $2 \mathrm{~mm}$ long was 
recorded from the initiation of radicle emergence at two hours interval up to 36 hours for each replication (International Seed Testing Association, 2012).

From the daily count data, the percentage radicle emergence $(1 \mathrm{~mm}$ and $2 \mathrm{~mm})$, Mean Just Germination Time (MJGT) and Mean Germination Time (MGT) was calculated using the following formula.

Radicle emergence with $1 \mathrm{~mm}$ length $(\%)=$ No. of seeds with $1 \mathrm{~mm}$ radicle length / Total no. of seeds sown $x$ 100

Radicle emergence with $2 \mathrm{~mm}$ length $(\%)=$ No. of seeds with $2 \mathrm{~mm}$ radicle length / Total no. of seeds sown $\times 100$

...Eq. 3

The first appearance of radicle, which is termed as Mean Just Germination Time and the Mean Germination Time, which is the mean lag period, to radical emergence was calculated using the following formula proposed by Ellis and Roberts (1980) and expressed in hours.

MJGT $=\Sigma \mathrm{nD} / \Sigma \mathrm{n}$

....Eq. 4

$\{$ Where, $n=$ number of seeds germinated (first appearance of the radicle) at time $D, D=$ hours from the beginning of the germination test, $\Sigma n=$ final number of radicle emergence $\}$

MGT $=\Sigma \mathrm{nD} / \Sigma \mathrm{n}$

\{Where, $n=$ number of seeds germinated (with $2 \mathrm{~mm}$ radicle emergence) at time $D, D=$ hours from the beginning of the germination test, $\Sigma n=$ final number of radicle emergence $\}$

\section{Electrical conductivity (EC) of seed leachate test}

4 replicates of 25 seeds in each seed lot were prewashed with distilled water to remove the adhere chemicals and then soaked in $50 \mathrm{ml}$ of distilled water for 16 hours. After soaking, the seed steep water was decanted to obtain the seed leachate. The electrical conductivity of the seed leachate was calculated in a digital conductivity meter with a cell constant of one and expressed as $\mathrm{dSm}^{-1}$ (Presley, 1958).

\section{Dehydrogenase enzyme activity (DA) test}

4 replicates of 25 seeds in each seed lot were preconditioned by soaking in water for 16 hours. Out of this, 10 seeds were taken at random and ready by remove the seed coat. The seeds were soaked in $0.5 \%$ of 2, 3, 5-Triphenyl tetrazolium chloride solution and kept in the dark at $40^{\circ} \mathrm{C}$ for 4 hours for staining. After staining, the seeds were soaked in $10 \mathrm{ml}$ of 2 methaxy ethanol (Methyl cellosolve) solution for 4 hour with intermittent stirring till the extraction of red colour formazan was terminated. The extract was decanted and the intensity of colour was read in a Spectrophotometer at $470 \mathrm{~nm}$. The OD values were reported as dehydrogenase enzyme activity (Kittock and law, 1968).

\section{Field emergence (FE) test}

Four replicates of hundred seeds in each seed lot were sown in raised nursery beds and the seedlings that emerged with normal root and shoot were counted after 15 days replication, and the mean values were expressed in percentage.

Field emergence $(\%)=$ No. of normal seedlings / Total no. of seeds sown $\mathrm{x} 100$ ....Eq. 6

\section{Statistical analysis}

Data obtained from the experiments were analyzed using an analysis of variance (ANOVA) as a factorial combination of treatments. Means were split on the basis of the least significant difference (LSD) only if $F$ test of ANOVA for treatments was significant at 0.05 probability level. Values in percent data were arcsine transformed before analysis. The significance of correlation coefficients was tested by Pearson correlation method using SPSS software.

\section{RESULTS AND DISCUSSION}

\section{Evaluation of physiological seed quality parameters}

The present study results in rice seed lots, all the physiological parameters were superior in high vigour seed lot $\left(L_{1}\right)$ to the low vigour seed lot $\left(L_{9}\right)$. The per cent increase for all the observed parameters viz., speed of germination, germination, dry matter production, vigour index and field emergence were 11, 26, 12, 34 and 27 $\%$, respectively (Table 1 ).

Similar results were also reported in corn seeds by Navratil and Burris (1980), who reported that the field emergence of the seed lots over five sowings seemed to be largely determined by the time taken to emerge, which was greatly influenced by temperature but was also significantly different among the seed lots. Similarly, the study on four seed lots of hybrid corn by TeKrony and Egli (1991) showed that low vigour seed lots emerged slowly and resulted in low germination, dry matter production, vigour index and field emergence.

The highest percentage of radicle emergence with $1 \mathrm{~mm}$ length was recorded at 34 hours (88\%), whereas the highest percentage of radicle emergence with $2 \mathrm{~mm}$ length was recorded at 36 hours (88\%). Among the different durations of manual and image analyser measurements, counting of radicle emergence with $1 \mathrm{~mm}$ length at 34 hours and counting of radicle emergence with $2 \mathrm{~mm}$ length at 36 hours were highly correlated with other seed vigour parameters. The results revealed that the high vigour seed lots recorded short MJGT and MGT compared to low vigour seed lots. The MJGT and MGT were minimum in lot 1 (26.64 hours and 33.12 hours) and the maximum in lot 10 (29.52 hours and 35.56 hours), respectively (Table 2 and 
Plate 1).

Low vigour seed lots required more time to reach $1 \mathrm{~mm}$ and $2 \mathrm{~mm}$ length of radicle emergence when compared to high vigour seed lots. Reasons for this delay has been interpreted as variations in the metabolic activity between the seeds with different vigour levels. The seed lots with high metabolic activity respond quickly for imbibition and proceed further for DNA repair, enzyme synthesis to break down the food materials. While low vigour seeds respond slowly (Matthews and Powell, 2011. These results are in agreement with the findings of Mavi et al. (2016) in cucurbits and sweet corn seeds. Radicle emergence test is a good indicator for predicting field emergence potential, determining seed quality and classifying seed lots into different vigour status was also confirmed in pepper, cabbage, soybean and radish seeds (Demir et al., 2008; Matthews et al., 2012).

Evaluation of biochemical seed quality parameters The lowest electrical conductivity of seed leachate was recorded in lot 1 and the highest was in lot 9 (0.034 and $0.051 \mathrm{dsm}^{-1}$ ), respectively and the maximum dehydrogenase activity was recorded in lot 1 and the minimum was recorded in lot 9 (0.158 and 0.141 OD value), respectively (Fig. 1).

Similar results were also reported in groundnut seeds by Suganthi and Selvaraju (2017). The electrical conductivity of seed leachate was mainly governed by cell

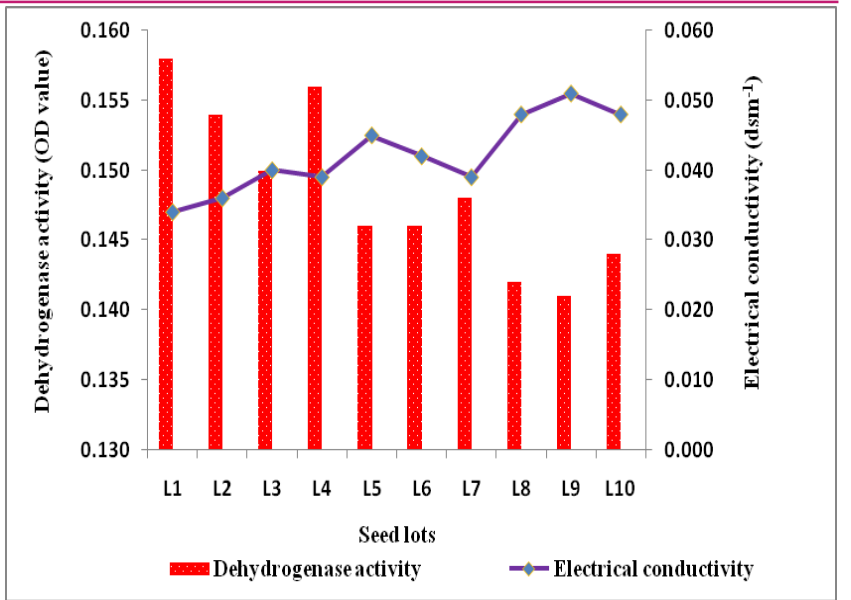

Fig. 1. Evaluation of electrical conductivity $\left(d s m^{-1}\right)$ and dehydrogenase activity (OD value) in rice seed lots.

wall permeability. Higher EC indicated higher permeability, respiration rate and metabolic activity (Doijode, 1985). The increase in electrical conductivity might be due to the loss of selective permeability of cell membrane by auto oxidation of polyunsaturated fatty acids, free radical peroxidation via auto-oxidation, lipooxygenase and hydrolytic damage (Francis and Coolbear, 1984). Similar results were also reported in groundnut seeds. The dehydrogenase enzyme activity, which is responsible for the respiration of the seed, reduces with the ageing of the seeds, which is also used as a vigour indicator (Suganthi and

Table 1. Evaluation of seed quality parameters in rice seed lots.

\begin{tabular}{|c|c|c|c|c|c|c|c|c|}
\hline Seed lots & $\begin{array}{l}\text { Speed of } \\
\text { germination }\end{array}$ & $\begin{array}{l}\text { Germina- } \\
\text { tion (\%) }\end{array}$ & $\begin{array}{l}\text { Root } \\
\text { length } \\
\text { (cm) }\end{array}$ & $\begin{array}{l}\text { Shoot } \\
\text { length } \\
(\mathrm{cm})\end{array}$ & $\begin{array}{l}\text { Dry matter } \\
\text { production } \\
\left(g_{10} \text { seed- }\right. \\
\left.\text { ling }^{-1}\right)\end{array}$ & $\begin{array}{l}\text { Vigour } \\
\text { index }\end{array}$ & $\begin{array}{l}100 \\
\text { seed } \\
\text { weight } \\
\text { (g) }\end{array}$ & $\begin{array}{l}\text { Field emer- } \\
\text { gence (\%) }\end{array}$ \\
\hline $\mathrm{L}_{1}$ & 8.3 & $96(78.46)$ & 22.8 & 10.5 & 0.073 & 3197 & 1.69 & $89(70.63)$ \\
\hline $\mathrm{L}_{2}$ & 8.2 & $95(77.08)$ & 22.4 & 10.1 & 0.071 & 3086 & 1.68 & $87(68.86)$ \\
\hline $\mathrm{L}_{3}$ & 8.2 & $91(72.54)$ & 22.2 & 10.4 & 0.069 & 2964 & 1.67 & $85(67.21)$ \\
\hline $\mathrm{L}_{4}$ & 8.1 & $94(75.82)$ & 22.3 & 10.3 & 0.070 & 3064 & 1.66 & $87(68.86)$ \\
\hline $\mathrm{L}_{5}$ & 8.0 & $87(68.86)$ & 22.6 & 10.0 & 0.069 & 2840 & 1.66 & $80(63.43)$ \\
\hline $\mathrm{L}_{6}$ & 7.9 & $88(69.73)$ & 22.9 & 10.3 & 0.070 & 2918 & 1.66 & $83(65.65)$ \\
\hline $\mathrm{L}_{7}$ & 8.0 & $89(70.63)$ & 21.8 & 10.4 & 0.068 & 2872 & 1.65 & $84(66.42)$ \\
\hline $\mathrm{L}_{8}$ & 7.9 & $79(62.72)$ & 21.8 & 10.2 & 0.066 & 2528 & 1.65 & 73 (58.69) \\
\hline $\mathrm{L}_{9}$ & 7.5 & $76(60.66)$ & 21.8 & 9.4 & 0.065 & 2371 & 1.64 & $70(56.79)$ \\
\hline $\mathrm{L}_{10}$ & 7.5 & $78(62.02)$ & 21.0 & 10.0 & 0.062 & 2418 & 1.64 & $74(59.34)$ \\
\hline Mean & 8.0 & $87(68.86)$ & 22.2 & 10.2 & 0.068 & 2826 & 1.66 & $81(64.15)$ \\
\hline Sed & 0.11 & 1.3 & 0.30 & 0.16 & 0.0012 & 26.5 & 0.018 & 0.70 \\
\hline$C D(P=0.05)$ & 0.23 & 2.6 & 0.62 & 0.32 & 0.0024 & 54.1 & NS & 1.42 \\
\hline
\end{tabular}

Figure in parenthesis indicates arcsine value 


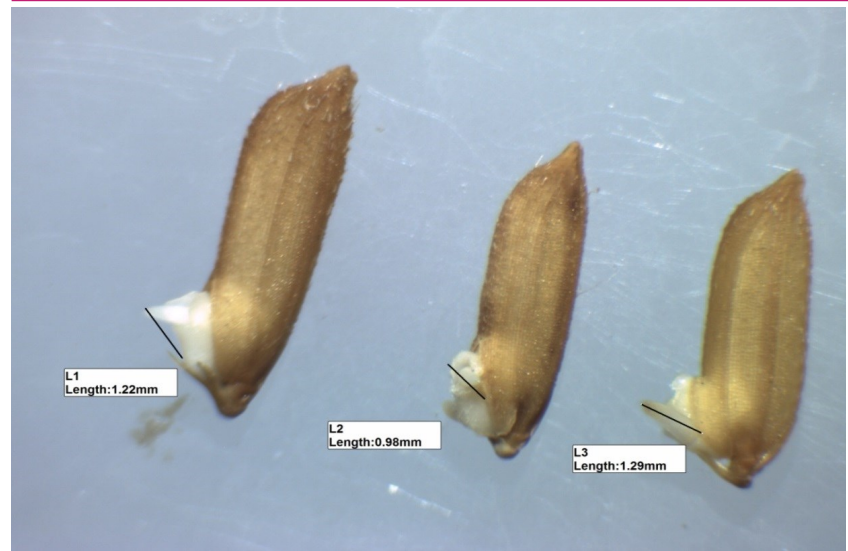

$1 \mathrm{~mm}$ radicle length at $34 \mathrm{~h}$

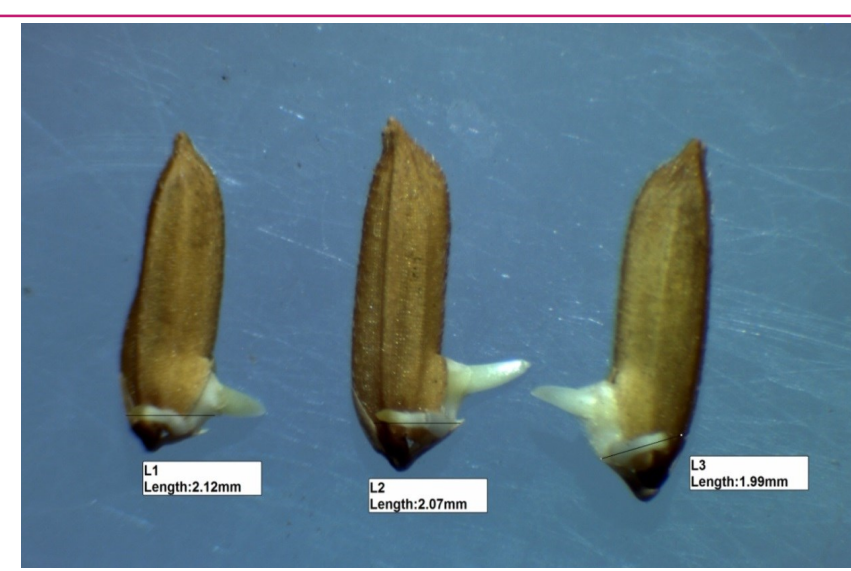

$2 \mathrm{~mm}$ radicle length at $36 \mathrm{~h}$

Plate 1. Radicle emergence with $1 \mathrm{~mm}$ and $2 \mathrm{~mm}$ length in rice seed lots.

Selvaraju, 2017).

\section{Correlation between radicle emergence and seed} vigour parameters

Correlation analysis was carried out to assess the relationship between seed vigour parameters viz., speed of germination, germination (\%), dry matter production (g 10 seedlings $^{-1}$ ), vigour index, mean just germination time (h), mean germination time (h), electrical conductivity of seed leachate $\left(\mathrm{dsm}^{1}\right)$, dehydrogenase activity (OD Value), hundred seed weight (g), field emergence (\%) and 1 and $2 \mathrm{~mm}$ radicle emergence percent in ten different seed lots.
Among the various seed vigour parameters studied, dehydrogenase activity $\left(0.951^{* *}\right)$, germination $\left(0.905^{\star *}\right)$, vigour index $\left(0.895^{* *}\right)$, hundred seed weight $\left(0.895^{\star *}\right)$, field emergence $\left(0.886^{\star *}\right)$, speed of germination $\left(0.841^{* *}\right)$ and dry matter production $\left(0.841^{* *}\right)$ had highly significant positive correlation with the percentage of radicle emergence with $1 \mathrm{~mm}$ length at $34^{\text {th }}$ hour followed by $28^{\text {th }}$ hour. Whereas, the electrical conductivity of seed leachate $\left(-0.943^{* *}\right)$, mean germination time $\left(-0.931^{* *}\right)$ and mean just germination time $\left(-0.902^{* *}\right)$ had a significant negative correlation with the percentage of radicle emergence with $1 \mathrm{~mm}$ length at $34^{\text {th }}$ hour followed by $28^{\text {th }}$ hour. However, the

Table 2. Comparison of radicle emergence to 1 and $2 \mathrm{~mm}$ length through manual and image analyzer measurement in rice seed lots.

\begin{tabular}{lllllll}
\hline & & & \multicolumn{2}{c}{ Manual measurement } & \multicolumn{2}{c}{ Image analyser measurement } \\
\cline { 5 - 7 } Seed lots & $\begin{array}{l}\text { MJGT } \\
\text { (h) }\end{array}$ & $\begin{array}{l}\text { MGT } \\
\text { (h) }\end{array}$ & $\begin{array}{l}\text { Radicle emer- } \\
\text { gence with 1mm } \\
\text { length @ 34h (\%) }\end{array}$ & $\begin{array}{l}\text { Radicle emer- } \\
\text { gence with 2mm } \\
\text { length @ 36h (\%) }\end{array}$ & $\begin{array}{l}\text { Radicle emer- } \\
\text { gence with 1mm } \\
\text { length @ 34h (\%) }\end{array}$ & $\begin{array}{l}\text { Radicle emer- } \\
\text { gence with 2mm } \\
\text { length @ 36h (\%) }\end{array}$ \\
\hline $\mathrm{L}_{1}$ & 26.64 & 33.12 & $94(75.82)$ & $100(89.71)$ & $95(77.08)$ & $99(84.26)$ \\
$\mathrm{L}_{2}$ & 27.12 & 33.12 & $90(71.56)$ & $98(81.87)$ & $92(73.57)$ & $98(81.87)$ \\
$\mathrm{L}_{3}$ & 26.88 & 33.60 & $88(69.73)$ & $96(78.46)$ & $89(70.63)$ & $95(77.08)$ \\
$\mathrm{L}_{4}$ & 26.88 & 33.36 & $90(71.56)$ & $98(81.87)$ & $91(72.54)$ & $97(80.02)$ \\
$\mathrm{L}_{5}$ & 28.56 & 34.56 & $86(68.02)$ & $88(69.73)$ & $85(67.21)$ & $89(70.63)$ \\
$\mathrm{L}_{6}$ & 27.84 & 34.80 & $88(69.73)$ & $84(66.42)$ & $87(68.86)$ & $84(66.42)$ \\
$\mathrm{L}_{7}$ & 28.08 & 34.32 & $88(69.73)$ & $84(66.42)$ & $88(69.73)$ & $84(66.42)$ \\
$\mathrm{L}_{8}$ & 29.04 & 35.28 & $86(68.02)$ & $78(69.73)$ & $86(68.02)$ & $78(62.02)$ \\
$\mathrm{L}_{9}$ & 29.04 & 35.76 & $84(66.42)$ & $74(59.34)$ & $83(65.65)$ & $73(58.69)$ \\
$\mathrm{L}_{10}$ & 29.52 & 35.52 & $84(66.42)$ & $76(60.66)$ & $84(66.42)$ & $78(62.02)$ \\
Mean & 27.96 & 34.34 & $88(69.73)$ & $88(69.73)$ & $88(69.73)$ & $88(69.73)$ \\
$\mathrm{SEd}$ & 0.370 & 0.535 & 1.04 & 1.79 & 1.22 & 2.10 \\
$\mathrm{CD}(\mathrm{P}=0.05)$ & 0.756 & 1.094 & 2.12 & 3.67 & 2.50 & 4.29 \\
\hline
\end{tabular}

Figure in parenthesis indicates arcsine value; MJGT- Mean just germination time (h); MGT- Mean germination time (h) 
Chinnasamy, G. P. et al. / J. Appl. \& Nat. Sci. 13 (SI), 86 - 93 (2021)

\begin{tabular}{|c|c|c|c|c|c|c|c|c|c|c|c|c|c|c|}
\hline & SOG & GER & DMP & VI & MJGT & MGT & EC & DA & HSW & FE & $\begin{array}{l}\text { RE } \\
28 h\end{array}$ & $\begin{array}{l}\text { RE } \\
30 h\end{array}$ & $\begin{array}{l}\text { RE } \\
32 \mathrm{~h}\end{array}$ & $\begin{array}{l}\text { RE } \\
34 \mathrm{~h}\end{array}$ \\
\hline SOG & 1 & & & & & & & & & & & & & \\
\hline GER & $.907^{*}$ & 1 & & & & & & & & & & & & \\
\hline DMP & $.921^{* *}$ & $.909^{* *}$ & 1 & & & & & & & & & & & \\
\hline VI & $.925^{* *}$ & $.992^{* *}$ & $.943^{* *}$ & 1 & & & & & & & & & & \\
\hline MJGT & $-.872^{* *}$ & $-.940^{* *}$ & $-.885^{* *}$ & $-.936 *$ & 1 & & & & & & & & & \\
\hline MGT & $-.897^{* *}$ & $-.970^{* *}$ & $-.851^{* *}$ & $-.946^{* *}$ & $.945^{* *}$ & 1 & & & & & & & & \\
\hline EC & $-.863^{* *}$ & $-.966^{* *}$ & $-.858^{* *}$ & $-.954^{* *}$ & $.904^{* *}$ & $.942^{* *}$ & 1 & & & & & & & \\
\hline DA & $.785^{\star *}$ & $.931^{* *}$ & $.801^{* *}$ & $.905^{* *}$ & $-.905^{* *}$ & $-.954^{* *}$ & $-.923^{* *}$ & 1 & & & & & & \\
\hline HSW & $.860^{* *}$ & $.866^{* *}$ & $.893^{* *}$ & $.881^{* *}$ & $-.855^{* *}$ & $-.880^{* *}$ & $-.861^{* *}$ & $.834^{* *}$ & 1 & & & & & \\
\hline FE & $.873^{* t}$ & $.989^{* \star}$ & $.873^{* *}$ & $.983^{* *}$ & $-.926^{* *}$ & $-.943^{* *}$ & $-.973^{* *}$ & $.914^{* *}$ & $.827^{* *}$ & 1 & & & & \\
\hline RE $28 \mathrm{~h}$ & $.778^{* *}$ & $.831^{* *}$ & $.801^{* *}$ & $.841^{* *}$ & $-.711^{\star}$ & $-.785^{* *}$ & $-.782^{* *}$ & $.710^{*}$ & $.849^{* *}$ & $.813^{* *}$ & 1 & & & \\
\hline RE 30h & .575 & .616 & $.656^{*}$ & .627 & $-.709^{*}$ & $-.674^{*}$ & -.551 & $.688^{*}$ & $.804^{* *}$ & .567 & $.714^{*}$ & 1 & & \\
\hline RE 32h & .441 & .458 & .500 & .479 & -.587 & -.473 & -.326 & .568 & .356 & .426 & .218 & .586 & 1 & \\
\hline RE $34 \mathrm{~h}$ & $.841^{* *}$ & $.905^{* *}$ & $.841^{\text {** }}$ & $.895^{* *}$ & $-.902^{* *}$ & $-.931^{* *}$ & $-.943^{* *}$ & $.951^{* *}$ & $.895^{* *}$ & $.886^{* *}$ & $.670^{*}$ & $.646^{*}$ & .463 & 1 \\
\hline
\end{tabular}

** Significant at 0.01 level, * Significant at 0.05 level , SOG - Speed of germination, GER - Germination (\%), DMP - Dry matter production (g/ 10 seedling), VI-Vigour index, MJGT-Mean just germination time (h),MGT - Mean germination time (h), EC - Electrical conductivity of seed leachate $\left(\mathrm{dsm}^{-1}\right), \mathrm{DA}$ - Dehydrogenase activity (OD value), HSW - Hundred seed weight (g), FE - Field emergence (\%), RE - Radicle emergence (\%)

Table 4. Correlation between seed vigour parameters and radicle emergence with $2 \mathrm{~mm}$ length (\%) in rice seed lots.

\begin{tabular}{|c|c|c|c|c|c|c|c|c|c|c|c|c|c|c|}
\hline & SOG & GER & DMP & VI & MJGT & MGT & EC & DA & HSW & FE & $\begin{array}{l}\mathrm{RE} \\
\mathbf{3 0 \mathrm { h }}\end{array}$ & $\begin{array}{l}\mathrm{RE} \\
32 \mathrm{~h}\end{array}$ & $\begin{array}{l}\mathrm{RE} \\
\mathbf{3 4 h}\end{array}$ & $\begin{array}{l}\text { RE } \\
36 \mathrm{~h}\end{array}$ \\
\hline$\overline{S O G}$ & 1 & & & & & & & & & & & & & \\
\hline GER & $.907^{* *}$ & 1 & & & & & & & & & & & & \\
\hline DMP & $.921^{* *}$ & $.909^{* *}$ & 1 & & & & & & & & & & & \\
\hline VI & $.925^{* *}$ & $.992^{* *}$ & $.943^{* *}$ & 1 & & & & & & & & & & \\
\hline MJGT & $-.872^{* *}$ & $-.940^{* *}$ & $-.885^{* *}$ & $-.936^{* *}$ & 1 & & & & & & & & & \\
\hline MGT & $-.897^{* *}$ & $-.970^{* *}$ & $-.851^{* \star}$ & $-.946^{* *}$ & $.945^{* *}$ & 1 & & & & & & & & \\
\hline EC & $-.863^{* *}$ & $-.966^{* *}$ & $-.858^{* *}$ & $-.954^{* *}$ & $.904^{* *}$ & $.942^{* *}$ & 1 & & & & & & & \\
\hline DA & $.785^{* *}$ & $.931^{* *}$ & $.801^{\star *}$ & $.905^{* *}$ & $-.905^{\star *}$ & $-.954^{* *}$ & $-.923^{* *}$ & 1 & & & & & & \\
\hline HSW & $.860^{* *}$ & $.866^{* *}$ & $.893^{* *}$ & $.881^{* *}$ & $-.855^{* *}$ & $-.880^{\star *}$ & $-.861^{* \star}$ & $.834^{* *}$ & 1 & & & & & \\
\hline FE & $.873^{* *}$ & $.989^{* *}$ & $.873^{* *}$ & $.983^{* *}$ & $-.926^{* *}$ & $-.943^{* *}$ & $-.973^{* *}$ & $.914^{* *}$ & $.827^{* *}$ & 1 & & & & \\
\hline RE 30h & $.857^{* *}$ & $.908^{* *}$ & $.888^{* *}$ & $.926^{* *}$ & $-.849^{* \star}$ & $-.876^{\star *}$ & $-.837^{* \star}$ & $.901^{* *}$ & $.842^{* *}$ & $.884^{* *}$ & 1 & & & \\
\hline RE 32h & $.759^{*}$ & $.751^{*}$ & $.826^{* *}$ & $.775^{* *}$ & $-.785^{\star *}$ & $-.786^{* *}$ & $-.669^{*}$ & $.791^{* *}$ & $.900^{* *}$ & $.685^{*}$ & $.874^{* *}$ & 1 & & \\
\hline RE 34h & $.752^{*}$ & $.708^{*}$ & $.738^{*}$ & $.719^{*}$ & $-.798^{* *}$ & $-.777^{* *}$ & -.603 & $.781^{* *}$ & $.743^{*}$ & $.643^{*}$ & $.838^{* * *}$ & $.914^{* *}$ & 1 & \\
\hline RE 36h & $.913^{* *}$ & $.878^{* *}$ & $.810^{* *}$ & $.873^{* *}$ & $-.852^{* *}$ & $-.930^{* *}$ & $-.827^{* *}$ & $.864^{* *}$ & $.875^{* *}$ & $.894^{* *}$ & $.872^{* *}$ & $.853^{* *}$ & $.862^{* *}$ & 1 \\
\hline
\end{tabular}

** Significant at 0.01 level , * Significant at 0.05 level, SOG - Speed of germination, GER - Germination (\%), DMP - Dry matter production (g/ 10 seedling), VI - Vigour index, MJGT - Mean just germination time (h), MGT - Mean germination time (h), EC - Electrical conductivity of seed leachate $\left(\mathrm{dsm}^{-1}\right), \mathrm{DA}-$ Dehydrogenase activity (OD value), HSW - Hundred seed weight (g), FE - Field emergence (\%), RE - Radicle emergence (\%)

speed of germination, germination, vigour index and electrical conductivity of seed leachate and field emergence had no correlation with the percentage of radicle emergence with $1 \mathrm{~mm}$ length at 30 and 32 hour (Table 3).

Similarly, the speed of germination $\left(0.913^{\star *}\right)$, field emergence $\left(0.894^{* *}\right)$, germination $\left(0.878^{* *}\right)$, hundred seed weight $\left(0.875^{* *}\right)$, vigour index $\left(0.873^{* *}\right)$, dehydrogenase activity $\left(0.864^{* *}\right)$ and dry matter production $\left(0.810^{* *}\right)$ had highly significant positive correlation with the percentage of radicle emergence with $2 \mathrm{~mm}$ length at $36^{\text {th }}$ hour followed by 30,32 , and 34 hour. Whereas, Mean germination time $\left(0.930^{* *}\right)$, mean just germination time $\left(-0.852^{* *}\right)$ and electrical conductivity of seed leachate $\left(-0.827^{* *}\right)$ had highly significant negative correlation with the percentage of radicle emergence with $2 \mathrm{~mm}$ length at $36^{\text {th }}$ hour followed by 30,32 , and 34 hour. However, the electrical conductivity of seed leachate had no correlation with the percent- 
Table 5. Classification of seed lots based on mean germination time and field emergence in rice seed lots.

\begin{tabular}{lll}
\hline $\begin{array}{l}\text { Seed quality } \\
\text { classification }\end{array}$ & $\begin{array}{l}\text { Mean germina- } \\
\text { tion time (h) }\end{array}$ & $\begin{array}{l}\text { Field emergence } \\
\mathbf{( \% )}\end{array}$ \\
\hline High vigour & $<34$ & $>85$ \\
Medium vigour & $34-35$ & $80-85$ \\
Low vigour & $>35$ & $<80$ \\
\hline
\end{tabular}

age of radicle emergence with $2 \mathrm{~mm}$ length at $34^{\text {th }}$ hour (Table 4).

The current findings are in accordance with the results of Larsen et al. (1998), who found that mean germination time was highly correlated with time to emergence, plant growth and yield in field trials of oilseed rape. Better performance was seen for seed lots with an earlier rate of germination. According to Powell (1988), the low vigour seed lots with high mean germination time produced smaller and more variable seedlings and exhibited deteriorated seed characteristics resulting from either imposed ageing treatments or natural ageing. Mean germination time was significantly correlated to field emergence in three Italian rye grass species in all four sowing conditions and accounted for more than $80 \%$ of the variation in final field emergence. The seed lots with lower field emergence percentage were also slower to emerge and the mean germination time was highly correlated with $2 \mathrm{~mm}$ radicle emergence (Naylor, 2003).

\section{Relationship between the radicle emergence and field emergence}

In the present study, the radicle emergence and field emergence relationship were evaluated. In rice seed lots, the highest $R^{2}$ value $(0.7855)$ was observed in $34^{\text {th }}$ hours counting of radicle emergence with $1 \mathrm{~mm}$ length followed by $28,30,32$ hours and the highest $R^{2}$ value $(0.7951)$ was observed in $36^{\text {th }}$ hours counting of radicle emergence with $2 \mathrm{~mm}$ length followed by 30,32 and 34 hours (Fig. 2). A similar correlation between radicle emergence count and field emergence percentage was also reported by Luo et al. (2015) for the prediction of vigour potential in several crops viz., sweet corn, radish, brinjal and canola.

\section{Classification of seed lots based on mean germination time and field emergence}

From the results, the seed vigour was classified into three group's viz., high, medium and low vigour based on the relationship between mean germination time and field emergence. When the MGT was < 34 hours, the field emergence was exceeded 85 per cent, which was considered as high vigour; when the MGT was 34-35 hours, the field emergence was $80-85$ per cent, which
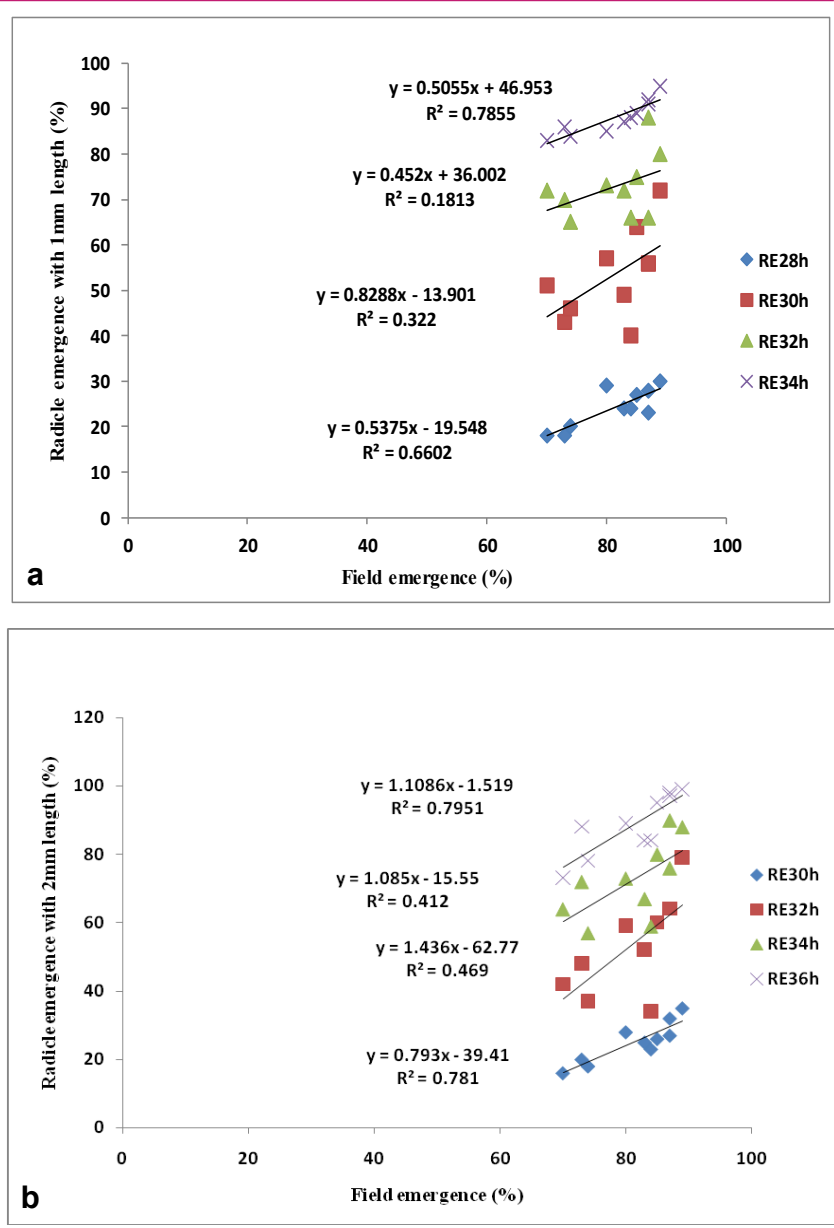

Fig. 2. Relationship between radicle emergence with $1 \mathrm{~mm}$ (a) \& $2 \mathrm{~mm}$ (b) length and field emergence in rice seed lots.

was considered as medium vigour; When the MGT was $>35$ hours, the field emergence was below 80 per cent, which was considered as low vigour (Table 5). The current results similar to the findings of Suganthi and Selvaraju (2017) who suggested that in groundnut seeds, when field emergence exceeded 85 per cent, the electrical conductivity was $<13 \mu \mathrm{S} \mathrm{cm} \mathrm{g}^{-1}$ and the seeds were considered as high vigour; when field emergence was between 70 - 85 per cent, the electrical conductivity was between $13-26 \mu \mathrm{Sm}^{-1} \mathrm{~g}^{-1}$ and it would be considered as medium vigour; and when field emergence fell below 70 per cent of the seeds are considered as low vigour with electrical conductivity values of $>26$ $\mu S \mathrm{~cm}^{-1} \mathrm{~g}^{-1}$.

\section{Conclusion}

Radicle emergence test is a quick test to predict different vigour level, field emergence potential and ranking seed lots. The radicle emergence test $(2 \mathrm{~mm}$ radicle length) was highly negatively correlated with mean germination time followed by the electrical conductivity of seed leachate and mean just germination time. It was 
positively correlated with field emergence followed by germination and dehydrogenase activity. The $R^{2}$ values between seed vigour parameters and radicle emergence test were significantly $(P=0.05)$ higher in $2 \mathrm{~mm}$ length of radicle emergence when compared with $1 \mathrm{~mm}$ length of radicle emergence. Finally, the study concluded that 36-hour MGT with the attainment of $2 \mathrm{~mm}$ radicle emergence percentage could be used as a quick method to assess rice seed lots' quality by the seed analysts and seed industry.

\section{Conflict of interest}

The authors declare that they have no conflict of interest.

\section{REFERENCES}

1. Abdul-Baki, A. A. \& Anderson, J. D. (1973). Vigor determination in soybean seed by multiple criteria 1. Crop Science, 13(6). 630-633. https://doi.org/10.2135/cropsci1 $973.0011183 \times 001300060013 x$.

2. Demir, I., Ermis, S., Mavi, K. \& Matthews, S. (2008). Mean germination time of pepper seed lots (Capsicum annuum L.) predicts size and uniformity of seedlings in germination tests and transplant modules. Seed Science and Technology, 36(1), 21-30. DOI: 10.15258/sst.2010.38.1.02.

3. Ellis, R. H. \& Roberts, E. H. (1980). The influence of temperature and moisture on seed viability period in barley (Hordeum distichum L.). Annals of Botany, 45(1), 31-37.

4. International Seed Testing Association (2012). International Rules for Seed Testing. International Seed Testing Association (ISTA). Bassersdorf, Switzerland.

5. International Seed Testing Association (2014). Seed Vigour Testing. International Rules for Seed Testing, , International Seed Testing Association (ISTA). Zurich, Switzerland.

6. International Seed Testing Association. (2016). Seed Vigour Testing. International Rules for Seed Testing, , International Seed Testing Association (ISTA). Zurich, Switzerland.

7. Kittock, D. L. \& Law, A. G. (1968). Relationship of seedling vigor to respiration and tetrazolium chloride reduction by germinating wheat seeds 1. Agronomy Journal, 60(3), 286-288.

8. Kolasinska, K., Szyrmer, J. \& Dul, S. (2000). Relationship between laboratory seed quality tests and field emergence of common bean seed. Seed Science and Technology, 31 (1), 54-70. (DOI: https://doi.org/10.2135/cropsci20 00.402 $470 x)$.

9. Larsen, S. Ugilt, Povlsen, F. Vestergaard, Eriksen, E. Nymann \& Pedersen, H.C. (1998). The influence of seed vigour on field performance and the evaluation of the applicability of the controlled deterioration vigour test in oil seed rape (Brassica napus) and pea (Pisum sativum). Seed Science and Technology, 26 (4), 627-641.

10. Luo, Y., Y.J. Guan, Y.T. Huang, J. Li, Z. Li. \& J. Hu. (2015). Single counts of radicle emergence provides an alternative method to test seed vigour in sweet corn. Seed Science and Technology, 43 (3),519-525.

11. Maguire, J. D. (1962). Speed of germination-aid in selection and evaluation for seedling emergence and vigor 1. Crop Science, 2(2), 176-177.

12. Matthews, S. \& Powell, A. (2011). Towards automated single counts of radicle emergence to predict seed and seedling vigour. Seed Testing International (ISTA Bulletin), 142, 44-48.

13. Matthews, S., Noli, E., Demir, I., Khajeh-Hosseini, M. \& Wagner, M. H. (2012). Evaluation of seed quality: from physiology to international standardization. Seed Science Research, 22(S1), S69-S73.

14. Mavi, K., Powell, A. A. \& Matthews, S. (2016). Rate of radicle emergence and leakage of electrolytes provide quick predictions of percentage normal seedlings in standard germination tests of radish (Raphanus sativus). Seed Science and Technology, 44(2), 393-409. (DOI: https:// doi.org/10.15258/sst.2016.44.2.12)

15. Navratil, R. J. \& Burris, J. S. (1980). Predictive equations for maize inbred emergence 1. Crop Science, 20(5), 567571. https://doi.org/10.2135/cropsci1980.001 1183X00200 $0050004 \mathrm{x}$

16. Naylor. (2003). Germination of seed lots of Italian ryegrass (Lolium multiflorum Lam.) after extended natural ageing in cool storage. Seed Science and Technology 31 (1), 177-185.

17. Powell. (1988). Seed vigour and field establishment. $A d-$ vances in research and technology of seeds. 30(3), 56-66. (DOI: https://doi.org/10.1093/jxb/erv490).

18. Presley, J. T. (1958). Relation of protoplast permeability to cotton seed viability and predisposition to seedling disease. Plant Disease Reporter, 42(7), 852.

19. Qun, S., Wang, J. H. \& Sun, B. Q. (2007). Advances on seed vigor physiological and genetic mechanisms. Agricultural Sciences in China, 6(9), 1060-10 66.

20. Suganthi, A. \& Selvaraju, P. (2017). Fixing accelerated ageing test period and evaluation of physical, physiological and biochemical changes during accelerated ageing in groundnut CO 7 pods. International Journal of chemical studies, 5(6), 174-179.

21. Tekrony, D. M. \& Egli, D. B. (1991). Relationship of seed vigor to crop yield: a review. Crop Science, 31(3), 816822. 